\title{
Community-acquired pneumonia: economics of inpatient medical care vis-à-vis clinical severity*,**
}

\author{
Pneumonia adquirida na comunidade: economia de cuidados médicos em \\ regime de internamento, em relação à gravidade clínica
Vojislav Cupurdija, Zorica Lazic, Marina Petrovic, Slavica Mojsilovic, Ivan Cekerevac, Nemanja Rancic, Mihajlo Jakovljevic

\begin{abstract}
Objective: To assess the direct and indirect costs of diagnosing and treating community-acquired pneumonia (CAP), correlating those costs with CAP severity at diagnosis and identifying the major cost drivers. Methods: This was a prospective cost analysis study using bottom-up costing. Clinical severity and mortality risk were assessed with the pneumonia severity index (PSI) and the mental Confusion-Urea-Respiratory rate-Blood pressure-age $\geq 65$ years (CURB-65) scale, respectively. The sample comprised 95 inpatients hospitalized for newly diagnosed CAP. The analysis was run from a societal perspective with a time horizon of one year. Results: Expressed as mean \pm standard deviation, in Euros, the direct and indirect medical costs per CAP patient were $696 \pm 531$ and $410 \pm 283$, respectively, the total per-patient cost therefore being 1,106 \pm 657 . The combined budget impact of our patient cohort, in Euros, was 105,087 (66,109 and 38,979 in direct and indirect costs, respectively). The major cost drivers, in descending order, were the opportunity cost (lost productivity); diagnosis and treatment of comorbidities; and administration of medications, oxygen, and blood derivatives. The CURB-65 and PSI scores both correlated with the indirect costs of CAP treatment. The PSI score correlated positively with the overall frequency of use of health care services. Neither score showed any clear relationship with the direct costs of CAP treatment. Conclusions: Clinical severity at admission appears to be unrelated to the costs of CAP treatment. This is mostly attributable to unwarranted hospital admission (or unnecessarily long hospital stays) in cases of mild pneumonia, as well as to over-prescription of antibiotics. Authorities should strive to improve adherence to guidelines and promote cost-effective prescribing practices among physicians in southeastern Europe.
\end{abstract}

Keywords: Pneumonia; Cost of illness; Costs and cost analysis; Health care costs; Hospitalization; Severity of illness index.

\section{Resumo}

Objetivo: Avaliar os custos médicos diretos e indiretos de diagnóstico e tratamento para pacientes com pneumonia adquirida na comunidade (PAC), correlacionando-os com a gravidade da PAC ao diagnóstico e identificando os principais fatores de custo. Métodos: Análise de custos prospectiva utilizando custo bottom-up. A gravidade clínica e o risco de mortalidade foram determinados através de pneumonia severity index (PSI) e a escala mental Confusion-Urea-Respiratory rate-Blood pressure-age $\geq 65$ years (CURB-65), respectivamente. A amostra foi composta por 95 pacientes hospitalizados devido a PAC recém-diagnosticada. A análise foi realizada em uma perspectiva social com um horizonte de tempo de um ano. Resultados: Expressos em média \pm desvio-padrão em euros, os custos médicos diretos e indiretos por paciente com PAC foram de $696 \pm 531$ e $410 \pm 283$, respectivamente, sendo, portanto, o custo total por paciente de $1.106 \pm 657$. 0 impacto orçamentário combinado deste grupo de pacientes em euros foi de 105.087 (66.109 e 38.979 nos custos diretos e indiretos, respectivamente). Os principais fatores de custo, em ordem descendente, foram custo de oportunidade (perda de produtividade); diagnóstico e tratamento de comorbidades; e administração de medicamentos, oxigênio e derivados do sangue. Os escores CURB-65 e PSI correlacionaram-se com os custos indiretos do tratamento da PAC. 0 escore PSI correlacionou-se positivamente com a frequência global no uso de serviços médicos. Nenhum dos escores mostrou uma relação clara com os custos diretos do tratamento da PAC. Conclusões: A gravidade clínica na admissão parece não se correlacionar com os custos do tratamento da PAC. Esses custos são principalmente causados por internações hospitalares desnecessárias (ou por internação desnecessariamente prolongada) em casos de pneumonia leve, assim como pela prescrição exagerada de antibióticos. As autoridades devem se esforçar para melhorar a adesão às diretrizes e promover práticas de prescrição custo-efetivas entre os médicos do sudeste da Europa.

Descritores: Pneumonia; Efeitos psicossociais da doença; Custos e análise de custo; Custos de cuidados de saúde; Hospitalização; Índice de gravidade de doença.

*Study carried out at the Faculty of Medical Sciences, University of Kragujevac, Kragujevac, Serbia.

Correspondence to: Mihajlo Jakovljevic. Faculty of Medical Sciences, University of Kragujevac, Svetozara Markovica 69, 34000 Kragujevac, Serbia. Tel. 38134 306-800. Fax: 38134 306-800. E-mail: sidartagothama@gmail.com; jakovljevicm@medf.kg.ac.rs

Financial support: This study received financial support from the Ministry of Education, Science, and Technological Development of the Republic of Serbia (Grant no. 01175 014). Publication of the results was not contingent upon the approval of or subject to censorship by the Ministry.

Submitted: 18 August 2014. Accepted, after review: 5 December 2014.

${ }^{* *}$ A versão completa, em português, deste artigo está disponível em: www.jornaldepneumologia.com.br 


\section{Introduction}

Community-acquired pneumonia (CAP) remains an ongoing challenge for health care facilities specializing in pulmonary medicine and critical care, across the globe. ${ }^{(1)}$ lts treatment is still demanding, and outcomes remain unpredictable, despite the unprecedented innovation in the development of new antibiotics. ${ }^{(2)}$ One major cause of the difficulties experienced in and the frequently unsatisfactory clinical outcomes of the treatment of CAP is poor adherence to clinical practice guidelines, as demonstrated in a recent study conducted in Brazil. ${ }^{(3)}$ In the context of increased expectations that health care systems will deliver cost-effective care, the financial burden of CAP has attracted the attention of experts. ${ }^{(4)}$ Various measures have been proposed and implemented to contain the costs related to the care of patients with CAP while preserving satisfactory clinical outcomes. ${ }^{(5)}$ Among the most successful of such measures is prioritizing outpatient diagnosis and treatment over hospital admission. Commonly reported results of this strategy are lower frequency of hospital infections with multidrug-resistant bacteria and fewer resources spent on the diagnosis and treatment of associated comorbidities. ${ }^{(6)}$

In comparison with other countries in the Western Balkans, one peculiarity of Serbia, which is the largest health care market in the region, is that its health care system is rather typical of the broader Eastern European context. ${ }^{(7)}$ Health expenditures continue to grow faster than the gross domestic product available among the high- and upper middle-income economies of the region. ${ }^{(8)}$ The population continues to age while incidence and prevalence rates of the leading diseases common to the upper socioeconomic classes are still rising. ${ }^{(9)}$ Local data regarding the financial burden of CAP remain scarce across the region. ${ }^{(10)}$ Many policy makers have begun to realize that a more robust evidence base is needed in order to make informed decisions on resource allocation. In light of current weaknesses of regional health financing, funding the quest for knowledge of the local cost drivers of key clinical conditions represents a valuable investment in the future of emerging markets. ${ }^{(11)}$

\section{Methods}

This was a prospective non-interventional clinical study with retrospective insight into pneumonia-related resource use and the direct costs of medical care, as well as indirect costs associated with absenteeism and the related productivity losses. Our aim was to assess the direct and indirect costs of diagnosis and medical treatment of patients with CAP, as well as to determine whether those costs correlate with CAP severity (stage) and clinical status at diagnosis. The analysis was run from a societal perspective with a time horizon of one year, and we used bottom-up costing.

Patients were recruited from among inpatients recently diagnosed with CAP and admitted to the University of Kragujevac Center for Clinical Medicine, in Kragujevac, Serbia. The Center, which is one of several large tertiary care facilities in the country, with 1,300 beds, provides specialty care for central and western Serbia. Common clinical practice at the facility is mostly in line with current guidelines for the diagnosis and treatment of respiratory infections. ${ }^{(12)}$

We included patients $\geq 18$ years of age who had received a diagnosis of CAP, confirmed by laboratory tests and imaging. A diagnosis of CAP was defined by signs of new infiltration on chest X-rays, together with at least one of the following symptoms: newly occurring cough; abnormal body temperature $\left(<35.6^{\circ} \mathrm{C}\right.$ or $\left.>37.5^{\circ} \mathrm{C}\right)$; and an abnormal blood cell count, defined as leukocytosis with a "left shift" or neutropenia. Patients who had a recent prior hospital admission (within the last 15 days) for any reason were excluded, as were those presenting with clinical signs indicative of pulmonary tuberculosis and those with severe pneumonia, requiring urgent admission to the intensive care unit and assisted ventilation.

Patients were enrolled consecutively over a period of 16 months. They were assessed by the attending physicians (internists who were subspecialists in pulmonology). The majority of the eligible patients (those meeting the study criteria) were recruited. Annually, there are approximately 200 hospital admissions for CAP, as well as up to 500 cases of CAP treated on an outpatient basis, at the target facility. Approximately $30 \%$ of the inpatients initially included were lost to follow up, due to loss of contact; a change of permanent residence and contact data; or voluntary withdrawal from the study.

At admission, the clinical evolution and severity of the infection were assessed with the pneumonia 
severity index (PSI), ${ }^{(13)}$ as well as the score on the scale known as CURB-65, an acronym based on the key terms of each risk factor evaluated (i.e., mental Confusion, Urea, Respiratory rate, Blood pressure, and age $\geq 65$ years), which is used in order to quantify mortality risk. ${ }^{(14)}$ Both of these scales are physician-oriented and have been widely adopted as reliable and valid clinical instruments. They are used worldwide to inform decisions regarding treatment, as well as to evaluate the likely prognosis.

Follow-up and observation took place from September of 2012 through December of 2013. The patient sample was representative of the population of central Serbia. Clinical background data were obtained by the attending physicians during prospective clinical follow-up. The results of a variety of laboratory tests and other diagnostic measures, as well as physical examination findings, are provided for the first and last day of hospitalization. We also determined 30-day mortality after discharge.

Patterns of resource use-frequency of physical examinations, bronchoscopies, sputum cultures, blood cultures, chest X-rays, and blood tests, as well as drug doses, etc.-were prospectively reported by the attending physicians and nurses. Direct medical costs were calculated on the basis of data available in the University of Kragujevac Center for Clinical Medicine electronic database of discharge invoices. The database contained exact prices of goods and services consumed in relation to the diagnosis and treatment of CAP. These prices were registered, at the time that the services were provided, by the primary payer, the National Health Insurance Fund of the Republic of Serbia. ${ }^{(15)}$ We calculated indirect costs using Grossman's human capital approach. ${ }^{(16)}$ Pneumonia caused absenteeism and resulted in opportunity costs (lost productivity), as calculated on the basis of the length of hospital stay; employment status of the patient and caregiver; and history of home care. We monetized lost work time on the basis of monthly salaries by occupation, according to the current official average values published by the Republic of Serbia. ${ }^{(17)}$

All statistical analyses were performed with the SPSS Statistics software package, version 19.0 (IBM Corporation, Armonk, NY, USA). Continuous variables are presented as mean \pm standard deviation, with ranges or with 95\% confidence intervals. Categorical variables are presented as proportions of the sample as a whole. To test the significance of differences between pre- and post-treatment values for continuous variables, we used Student's t-tests for dependent samples or the Wilcoxon signedrank test, depending on the normality of the data distribution (Kolmogorov-Smirnov test results). The significance of differences between two independent samples for continuous variables was measured with Student's t-tests or the MannWhitney $\mathrm{U}$ test, also depending on the normality of the data distribution. For comparisons of continuous variables among three or more groups, we used one-way ANOVA or the Kruskal-Wallis test, again depending on the normality of the data distribution. Linear correlations between key variables were tested by Spearman's and Pearson's correlation coefficients. The strength of each correlation was assessed according to Cohen's kappa ( $\geq 0.5=$ extremely strong; 0.3-0.49 = moderate; and $\leq 0.29$ = weak). Predictors of fatal outcome were subjected to multiple logistic regression, and the results are expressed as odds ratios. The level of statistical significance was set at $p<0.05$.

Patient data were handled in accordance with the Declaration of Helsinki and with Serbian national legislation on biomedical research in human subjects. The study was approved by the Research Ethics Committee of the University of Kragujevac Center for Clinical Medicine (Protocol no. 01-2349).

\section{Results}

The study sample was well-balanced in terms of the gender distribution, males and females respectively accounting for $46(48.5 \%)$ and 49 (51.5\%) of the 95 patients evaluated. The mean age was $63.46 \pm 14.83$ years (range, 23-92 years), retired individuals comprising $52.6 \%$ of the sample. The most significant risk factors were smoking and low rates of vaccination (against influenza and Streptococcus pneumoniae). In the vast majority of the cases, the onset of the clinical symptoms of CAP occurred at least 7 days before hospital admission (Table 1). At admission, 11 (11.6\%) of the 95 patients exhibited a high degree of clinical severity (advanced stage), with impaired consciousness. The majority of patients had at least one significant comorbidity disorder, the most common comorbid condition being essential hypertension. According to the PSI scores at 
admission, there was a clear predominance of class 111 (score range, 71-90) and class IV (score range, 91-130). On the basis of the CURB-65 scores at admission, $58(61 \%)$ of the patients were in the low-risk group and therefore might have been candidates for outpatient treatment. Nevertheless, all of the patients in our sample were admitted to the hospital. The mean hospital stay was two weeks. Thereafter, 52 (54.7\%) of the 95 patients received home care, and the mean length of follow-up treatment was approximately ten days. In most cases, home care was provided by a member of the immediate or extended family. Although most of the patients recovered fully after hospital discharge, five died during the follow-up period. On the basis of the multiple logistic regression analysis we concluded that a single determinant, the CURB-65 score, is a significant predictor of mortality $(O R=12,60)$. All of the patients who died had been classified as

Table 1 - Baseline demographic characteristics, lifestyle risk factors, clinical severity, and mortality risk in a sample of patients hospitalized with community-acquired pneumonia in Serbia.

\begin{tabular}{|c|c|}
\hline Variable & $(\mathrm{N}=95)^{\mathrm{a}}$ \\
\hline Age & $63.46 \pm 14.83(23-92)$ \\
\hline Body mass index $\left(\mathrm{kg} / \mathrm{m}^{2}\right)$ & $24.58 \pm 5.36(13.84-41.40)$ \\
\hline \multicolumn{2}{|l|}{ Occupation } \\
\hline Unknown, n (\%) & $19(20)$ \\
\hline Unemployed, n (\%) & $7(7.4)$ \\
\hline Homemaker, n (\%) & $3(3.2)$ \\
\hline Retired, n (\%) & $50(52.6)$ \\
\hline Unskilled laborer, n (\%) & $11(11.6)$ \\
\hline Health care worker, n (\%) & $1(1.1)$ \\
\hline Farmer, n (\%) & $1(1.1)$ \\
\hline Self-employed, n (\%) & $3(3.2)$ \\
\hline Nursing home occupant, n (\%) & $2(2.1)$ \\
\hline Current smoker, n (\%) & $44(46.3)$ \\
\hline \multicolumn{2}{|l|}{ Smoking history (pack-years) } \\
\hline All patients & $18.32 \pm 22.85(0-100)$ \\
\hline Smokers only & $37.05 \pm 19.49(0.4-100)$ \\
\hline Previous vaccination against influenza & $1(1.1)$ \\
\hline Previous vaccination against Streptococcus pneumoniae & $1(1.1)$ \\
\hline Previous hospitalization for pneumonia, n (\%) & $14(14.7)$ \\
\hline History of alcohol consumption, $\mathrm{n}(\%)$ & $10(10.5)$ \\
\hline \multicolumn{2}{|l|}{ Pneumonia severity index } \\
\hline Total score & $85.08 \pm 33.95(13-182)$ \\
\hline Class $1(\leq 50), \mathrm{n}(\%)$ & $15(15.8)$ \\
\hline Class 11 (51-70), n (\%) & $18(18.9)$ \\
\hline Class 111 (71-90), n (\%) & $22(23.2)$ \\
\hline Class IV (91-130), n (\%) & $32(33.7)$ \\
\hline Class V (> 131-395), n (\%) & $8(8.4)$ \\
\hline \multicolumn{2}{|l|}{ CURB-65 mortality risk (score) } \\
\hline Low $(0-1), \mathrm{n}(\%)$ & $58(61.1)$ \\
\hline Moderate (2), n (\%) & $29(30.5)$ \\
\hline Severe (3-5), n (\%) & $8(8.4)$ \\
\hline length of hospital stay (days) & $14.62 \pm 7.081(3-48)$ \\
\hline Pre-admission duration of clinical signs and symptoms of CAP (days) & $6.44 \pm 5.60(1-30)$ \\
\hline Medical care provided by a family member, $\mathrm{n}(\%)$ & $52(54.7)$ \\
\hline \multicolumn{2}{|l|}{ Survival at 30 days after discharge } \\
\hline Yes, n (\%) & $90(94.7)$ \\
\hline No, n $(\%)$ & $5(5.3)$ \\
\hline
\end{tabular}

CURB-65: (scale based on) mental Confusion-Urea-Respiratory rate-Blood pressure-age $\geq 65$ years; and CAP: community-

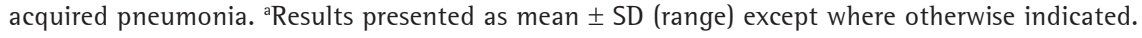


being in the CURB-65 moderate-risk or severerisk group.

Most of initial laboratory and blood test results were far more concerning than were those obtained at discharge, indicating successful recovery. Clinical complications of pulmonary infection were quite common. The most common such complications were (in descending order) respiratory insufficiency, $\mathrm{PaO}_{2}<60 \mathrm{mmHg}$, anemia, pleural effusion, and diarrhea (Table 2).

With regards to the economics of inpatient treatment for CAP, the diagnostic tests most frequently ordered by the attending physicians at the facility under study were chest X-ray, electrocardiography, laboratory analyses (hematology and biochemistry), arterial blood gas analysis, and spirometry (see Table 3). The medications most often prescribed for the treatment of CAP, according to the mean number of defined daily doses (DDDs) per patient, were as follows: levofloxacin (8.57 DDDs); methylprednisolone (5.04 DDDs); aminophylline (4.73 DDDs); ceftriaxone (3.54 DDDs); fluticasone+salmeterol $(0.73+2.20$ DDDs); ceftazidime (2.47 DDDs); amikacin (2.03 DDDs); fenoterol+ipratropium bromide $(0.76+1.60$ DDDs); ertapenem (1.83 DDDs); and acetylcysteine (1.81 DDDs). Antibiotics were the strongest single contributor to the acquisition costs of medications.

Expressed as mean \pm standard deviation (95\% $\mathrm{Cl}$ ), the direct and indirect costs per CAP patient, in Euros, were $696 \pm 531$ (30 to 589) and $410 \pm$ 283 (353 to 467), respectively, the total per to patient cost therefore being 1,106 \pm 657 (974 to 1,238$)$. The combined budget impact of our patient cohort was 105,087 (66,109 and 38,979 in direct and indirect costs, respectively). As can be seen in Table 4, the major cost drivers were as follows (values in Euros): general medical care (32 \pm 32 [26 to 39]); administration of medications, oxygen, and blood derivatives (178 \pm 211 [135 to 220]); laboratory tests and imaging (52 \pm 53 [42 to 63]); consultations and surgical interventions ( $30 \pm 38$ [22 to 38]); administrative and supporting services ( $2 \pm 20$ [ -2 to 6$]$ ); and the diagnosis and treatment of comorbidities (401 \pm 304 [340 to 462$]$ ).

After dividing the patients into subgroups according to their CURB-65 score (mortality risk) at admission, we identified no significant cost differentials among the low-, moderate-, and severerisk groups. Minor exceptions were oxygen and hormonal preparations, the administration of which was significantly more frequent among patients in the CURB-65 moderate- and severe-risk groups ( $p=0.046$ vs. the low-risk group). Paradoxically, the cost of CAP treatment was highest for the patients in the CURB-65 low-risk group. That finding can be explained by the fact that most of those cases were heavily dependent on home nursing care after early discharge, increasing the opportunity costs related to lost productivity ( $p=$ 0.002 vs. the moderate- and severe-risk groups).

There was a strong positive correlation between the PSI and CURB-65 scores $(r=0.663)$. We also found that the scores on the PSI and CURB-65 both correlated with the indirect costs of CAP treatment ( $r=-0.339$ and $r=-0.360$, respectively). Greater CAP severity, as indicated by a higher PSI score, correlated with the use of imaging and laboratory tests $(r=0.177)$, as well as with the administration of medications, oxygen and blood derivatives $(r=0.257)$. The PSI score also correlated positively with the overall per-patient frequency of use of health care services $(r=0.354)$.

The overall costs of care were substantially lower for CAP non-survivors than for CAP survivors. That is primarily attributable to the shorter hospital stays among the former ( $p=0.049)$, although the costs related to imaging, laboratory tests, physician consultations, and surgical costs were also significantly higher among the survivors $(p=0.004)$. Length of hospital stay exhibited strong positive correlations with direct, indirect, and total costs $(r=0.493, r=0.307$, and $r=$ 0.531 , respectively).

\section{Discussion}

The results presented here are the fruit of an attempt to analyze resource use, costs and clinical practice patterns on CAP in southeastern Europe, ${ }^{(10)}$ which, to our knowledge, constitutes the first such attempt. Similar data are readily available for a number of high income economies. In Switzerland, for example, the overall cost for a single episode of CAP in a child or adolescent is calculated to be 11,258 Swiss francs, or approximately 11,000 Euros. ${ }^{(18)}$ These costs vary widely among economies. In Poland, the mean cost for outpatient treatment of CAP is only 186 zlotys, or approximately 43 Euros. ${ }^{(19)}$ To date, there have been only a few cost-of-illness studies on respiratory disorders in Eastern Europe, and most of those have focused on COPD, confirming its huge economic burden. Such studies have shown 
Table 2 - Clinical parameters, symptoms, comorbidities, and clinical complications in a sample of patients hospitalized with community-acquired pneumonia in Serbia.

\begin{tabular}{|c|c|c|}
\hline Category & Variable & $(\mathrm{N}=95)$ \\
\hline \multirow{12}{*}{ Clinical presentation } & Body temperature $\left({ }^{\circ} \mathrm{C}\right)$, mean \pm SD (range) & $38.19 \pm 0.94(36-40)$ \\
\hline & Respiratory rate (breaths/min), mean \pm SD (range) & $19.61 \pm 4.73(12-36)$ \\
\hline & Heart rate $(\mathrm{bpm})$, mean \pm SD (range) & $94.45 \pm 18.58(55-150)$ \\
\hline & Systolic blood pressure (mmHg), mean \pm SD (range) & $124.37 \pm 19.16(75-170)$ \\
\hline & Diastolic blood pressure (mmHg), mean \pm SD (range) & $75.05 \pm 10.30(55-110)$ \\
\hline & Cough, n $(\%)$ & $80(84.2)$ \\
\hline & Productive cough, $\mathrm{n}(\%)$ & $49(51.6)$ \\
\hline & Dyspnea, n (\%) & $55(57.9)$ \\
\hline & Chest pain, $\mathrm{n}(\%)$ & $44(46.3)$ \\
\hline & Impaired consciousness, n (\%) & $11(11.6)$ \\
\hline & ICU admission, n (\%) & $9(9.5)$ \\
\hline & Artificial ventilation (assisted breathing), $\mathrm{n}(\%)$ & $0(0)$ \\
\hline \multirow{11}{*}{ Comorbid disorders } & Coronary heart disease, $\mathrm{n}(\%)$ & $17(17.9)$ \\
\hline & Heart failure, $\mathrm{n}(\%)$ & $21(22.1)$ \\
\hline & Heart valves damage, $n(\%)$ & $4(4.2)$ \\
\hline & Essential hypertension, $\mathrm{n}(\%)$ & $58(61.1)$ \\
\hline & Asthma, n (\%) & $10(10.5)$ \\
\hline & COPD, n (\%) & $21(22.1)$ \\
\hline & Kidney failure, n (\%) & $11(11.6)$ \\
\hline & Liver failure, n (\%) & $2(2.1)$ \\
\hline & Encephalopathy, n (\%) & $4(4.2)$ \\
\hline & Diabetes mellitus, $\mathrm{n}(\%)$ & $29(30.5)$ \\
\hline & Cancer (any malignancy), n (\%) & $6(6.3)$ \\
\hline \multirow{15}{*}{ Clinical complications } & Respiratory failure, n (\%) & $39(41.1)$ \\
\hline & $\mathrm{PaO}_{2}<60 \mathrm{mmHg}, \mathrm{n}(\%)$ & $32(33.7)$ \\
\hline & Pleural effusion, n (\%) & $23(24.2)$ \\
\hline & Pulmonary embolism, n (\%) & $1(1.1)$ \\
\hline & Pneumothorax, n (\%) & $0(0)$ \\
\hline & Heart failure, $\mathrm{n}(\%)$ & $17(17.9)$ \\
\hline & Gastrointestinal bleeding, $\mathrm{n}(\%)$ & $1(1.1)$ \\
\hline & Diarrhea, n (\%) & $21(22.1)$ \\
\hline & Hemoptysis, n (\%) & $9(9.5)$ \\
\hline & Empyema, n (\%) & $1(1.1)$ \\
\hline & Leukopenia, n (\%) & $2(2.1)$ \\
\hline & Anemia, n (\%) & $28(29.5)$ \\
\hline & Platelet deficiency, n (\%) & $2(2.1)$ \\
\hline & Stroke, n (\%) & $2(2.1)$ \\
\hline & Lung abscess, $\mathrm{n}(\%)$ & $3(3.2)$ \\
\hline
\end{tabular}

that the costs of treatment increase in parallel with the degree of COPD severity, according to the Global Initiative for Chronic Obstructive Lung Disease clinical classification. ${ }^{(20)}$ Intercountry comparisons of the costs of COPD treatment in Europe remain scarce, which hinders analysis of the key cost drivers and unique national health care settings. ${ }^{(21)}$ Estimates of the annual economic burden of CAP have exceeded common expectations in some markets, ranging from 63 million New Zealand dollars (approximately 42 million Euros) in New Zealand to 440.7 million pounds (approximately 574 million Euros) in the United Kingdom. ${ }^{(21)}$

Our finding that the length of hospital stay had a significant impact on the overall costs of CAP treatment is supported by well-documented evidence from other national settings. ${ }^{(22)}$ The strongest single cost driver in our sample was the opportunity cost related to work absenteeism. 
Table 3 - Patterns of resource use and frequency of pneumonia-related clinical interventions in a sample of patients hospitalized with community-acquired pneumonia in Serbia.

\begin{tabular}{|c|c|c|c|c|}
\hline \multirow[t]{2}{*}{ Intervention } & \multicolumn{2}{|c|}{ Per-patient frequency of use } & \multirow{2}{*}{$\begin{array}{c}\text { Total number of } \\
\text { examinations }\end{array}$} & \multirow{2}{*}{$\begin{array}{c}\text { Patients undergoing the } \\
\text { examinations } \\
\mathrm{n}(\%)\end{array}$} \\
\hline & Mean \pm SD & (range) & & \\
\hline Electrocardiography & $2.92 \pm 2.56$ & $0-14$ & 277 & 94 (98.9) \\
\hline Bronchoscopy & $0.18 \pm 0.39$ & $0-1$ & 17 & $17(17.9)$ \\
\hline Thoracocentesis & $0.09 \pm 0.39$ & $0-2$ & 9 & $6(6.4)$ \\
\hline Thoracic drainage & $0.01 \pm 0.10$ & $0-1$ & 1 & $1(1.1)$ \\
\hline Spirometry & $1.12 \pm 1.47$ & $0-7$ & 106 & $52(54.6)$ \\
\hline Chest CT & $0.27 \pm 0.45$ & $0-1$ & 26 & $26(27.4)$ \\
\hline Chest X-ray & $4.08 \pm 2.42$ & $0-20$ & 388 & $95(100)$ \\
\hline Blood culture & $0.26 \pm 0.64$ & $0-2$ & 25 & $15(15.8)$ \\
\hline Sputum culture & $0.94 \pm 1.45$ & $0-6$ & 89 & $40(42.1)$ \\
\hline Blood workup & $2.35 \pm 1.16$ & $0-8$ & 223 & 93 (97.9) \\
\hline Serum biochemistry & $2.34 \pm 1.23$ & $0-8$ & 222 & $92(96.8)$ \\
\hline Routine coagulation tests & $0.46 \pm 1.13$ & $0-9$ & 44 & $26(27.4)$ \\
\hline Viral immunoassays & $0.07 \pm 0.26$ & $0-1$ & 7 & $7(7.4)$ \\
\hline Blood-gas analysis & $2.20 \pm 3.64$ & $0-19$ & 209 & $54(56.8)$ \\
\hline
\end{tabular}

In developed countries, such a cost matrix is common for the majority of noncommunicable diseases, although it is less common for shortterm, communicable diseases. Our finding that the diagnosis and treatment of major comorbidities constituted the major cost driver could be explained by the rising incidence and financial burden of diseases common to the upper socioeconomic classes in Eastern Europe. Local evidence strongly supporting our findings can be found in other studies, also conducted in Serbia, evaluating the burdens of diabetes mellitus, COPD, addiction, fertility disorders, hepatitis, and cancer.(23-27)

Our data, which were acquired in a prospective manner within a methodologically appropriate framework, show that only the PSI score was predictive of the volume of health care services consumed. The CURB-65 and PSI scores both showed a satisfactory positive predictive value for the opportunity costs related to lost productivity. Nevertheless, we failed to identify any significant correlations between either of those clinical assessments of severity and the direct costs of CAP treatment. The lack of any such correlation is likely the result of poor physician adherence to guidelines. ${ }^{(28)}$ It seems that high prescription rates and the overuse of diagnostics measures (imaging and laboratory testing) are common in cases of CAP that are treated in the early, mild stages. Resource use and costs in more severe, advanced cases of CAP, in which the outcome is highly unpredictable, too frequently approach those seen in mild cases. It is likely that this is primarily attributable to long hospital stays, the routine administration of multiple antibiotics, and the use of the expensive parenteral medications preferred by physicians in the region. An excellent recent example of how adherence to clinical guidelines can downsize treatment expenditures and generate savings was provided in a controlled study of alcohol addiction conducted by our group. ${ }^{(29)}$ Our findings in the present study underscore the need for health care policies establishing stricter supervision of standard clinical practice. Analysis of the current state of the art of CAP treatment in Serbia, the largest health care market in the Western Balkans, indicates that the allocation of resources is inefficient. Providing local physicians with better evidence-based guidelines on costeffective medical interventions for pneumonia would likely improve clinical outcomes and generate savings.

The present study has some minor limitations. Conducting a prospective cost-of-illness study in parallel with a non-interventional clinical study in one large university hospital precludes a substantial increase in the sample size. A multicenter study conducted across several countries in the region might allow the knowledge of CAP treatment costs to be expanded beyond its current limits. Unfortunately, such an additional effort was not within the scope of the present study. Nevertheless, the results of our study, which we believe to be the first of its kind conducted in southeastern Europe, could lay the groundwork for improved 
Table 4 - Cost matrix of medical care for community-acquired pneumonia, including cost per patient and total expenditures, in a sample of patients hospitalized with community-acquired pneumonia in Serbia, 2012-2013.

\begin{tabular}{|c|c|c|}
\hline \multirow[t]{2}{*}{ Variable } & Per patient cost, in Euros ${ }^{\mathrm{a}}$ & \multirow{2}{*}{$\begin{array}{l}\text { Total cost, } \\
\text { in Euros }\end{array}$} \\
\hline & Mean \pm SD (range) & \\
\hline General medical care & $32 \pm 32$ (26 to 39$)$ & 3,086 \\
\hline Nursing care & $12.1 \pm 12.2(9.6$ to 14.5$)$ & 1,147 \\
\hline Consumables & $20.4 \pm 21.0(16.2$ to 24.6$)$ & 1,939 \\
\hline Medications, oxygen, blood, and blood derivatives & $178 \pm 211(135$ to 220$)$ & 16,894 \\
\hline Anti-infective medicines for systemic use & $165.4 \pm 199.1(125.3$ to 205.4$)$ & 15,710 \\
\hline Blood and blood derivatives & $1.1 \pm 10.5(-1.0$ to 3.2$)$ & 103 \\
\hline Antiseptics and disinfectants & $0.3 \pm 0.4$ (0.3 to 0.4$)$ & 31 \\
\hline $\begin{array}{l}\text { Cholesterol-lowering drugs (statins, fibrates, etc.) and } \\
\text { dietary supplements (vitamins and minerals) }\end{array}$ & $0.2 \pm 1.0(0.0$ to 0.4$)$ & 21 \\
\hline $\begin{array}{l}\text { Oxygen and systemic hormonal preparations (insulin, } \\
\text { bisphosphonates, steroids, etc.) }\end{array}$ & $10.8 \pm 22.7(6.3$ to 15.4$)$ & 1,029 \\
\hline Laboratory analysis and imaging diagnostics & $52 \pm 53$ (42 to 63$)$ & 4,989 \\
\hline Laboratory analysis & $29.8 \pm 29.8$ (23.9 to 35.8$)$ & 2,836 \\
\hline Simple X-rays & $3.4 \pm 2.7$ (2.9 to 4.4$)$ & 327 \\
\hline Nuclear medicine diagnostics & $0.3 \pm 1.9(-0.1$ to 0.6$)$ & 26 \\
\hline Tools and consumables & $0.1 \pm 0.5$ (0.0 to 0.2$)$ & 7 \\
\hline Cardiovascular interventional radiology & $12.3 \pm 35.6(5.2$ to 19.5$)$ & 1,173 \\
\hline Tools and consumables & $0.4 \pm 4.1(-0.4$ to 1.2$)$ & 40 \\
\hline Contrast agents, film, etc., for radiological services & $6.1 \pm 8.8(4.3$ to 7.9$)$ & 581 \\
\hline Consultations and surgical interventions & $30 \pm 38$ (22 to 38$)$ & 2,858 \\
\hline Consultations & $28.7 \pm 37.3$ (21.3 to 36.2$)$ & 2,731 \\
\hline Surgical interventions & $0.9 \pm 3.9(0.2$ to 1.7$)$ & 90 \\
\hline Dialysis and psychiatric treatment & $0.4 \pm 1.4(0.1$ to 0.7$)$ & 37 \\
\hline Administrative and supporting services & $2 \pm 20(-2$ to 6$)$ & 192 \\
\hline Diagnosis and treatment of comorbidities & $401 \pm 304$ (340 to 462$)$ & 38,092 \\
\hline Direct costs & $696 \pm 531$ (30 to 589$)$ & 66,109 \\
\hline Indirect costs & $410 \pm 283$ (353 to 467$)$ & 38,979 \\
\hline Total costs & $1,106 \pm 657$ (974 to 1,238$)$ & 105,087 \\
\hline
\end{tabular}

cost-efficiency in the treatment of pneumonia in the region.

As previously mentioned, the dominant cost drivers were the treatment of comorbid disorders, clinical complications, and the opportunity cost related to lost productivity. In view of the high incidence of respiratory infections in European communities, health care authorities should strive to improve adherence to guidelines and promote cost-effective prescribing practices among physicians in the region. Adopting long-term strategies aimed at reshaping the mindset of regional hospital staff would help contain costs and improve clinical outcomes.

\section{References}

1. Polverino E, Torres MA. Community-acquired pneumonia. Minerva Anestesiol. 2011;77(2):196-211.
2. Garre M, Potard M, Hiar 1, Tonnelier JM, Gentric A. Antimicrobial therapy of community-acquired pneumonia. New antibiotics, abbreviated course treatment, costbenefit analysis. Med Mal Infect. 2001;31(4):174-80.

3. Silveira CD, Ferreira CS, Corrêa Rde A. Adherence to guidelines and its impact on outcomes in patients hospitalized with community-acquired pneumonia at a university hospital. J Bras Pneumol. 2012;38(2):148-57.

4. Zhou QT, He B, Zhu H. Potential for cost-savings in the care of hospitalized low-risk community-acquired pneumonia patients in China. Value Health. 2009;12(1):40-6. http:// dx.doi.org/10.1111/j.1524-4733.2008.00410.x

5. Hoe LK, Keang LT. Hospitalized low-risk communityacquired pneumonia: outcome and potential for cost-savings. Respirology. 1999;4(3):307-9. http:// dx.doi.org/10.1046/j.1440-1843.1999.00197.x

6. Mandell LA, Wunderink RG, Anzueto A, Bartlett JG, Campbell GD, Dean NC, et al. Infectious Diseases Society of America/American Thoracic Society consensus guidelines on the management of community-acquired pneumonia in adults. Clin Infect Dis. 2007;44, Suppl 2:S27-72 http://dx.doi.org/10.1086/511159

7. Jakovljevic MB. Resource allocation strategies in Southeastern European health policy. Eur J Health 
Econ. 2013;14(2):153-9. http://dx.doi.org/10.1007/ s10198-012-0439-y

8. Jakovljevic MB. Health Expenditure Dynamics in Serbia 1995-2012. Hospital Pharmacology. 2014;1(3):180-3.

9. Jakovljevic M, Jovanovic M, Lazic Z, Jakovljevic V, Djukic A, Velickovic R, et al. Current efforts and proposals to reduce healthcare costs in Serbia. Ser J Exp Clin Res. 2011;12 (4):161-3. http://dx.doi.org/10.5937/sjecr1104161J

10. Jakovljevic M, Cupurdija V, Lazic Z. Cost of illness of community-acquired pneumonia. Review of the literature and possible strategies in the Serbian health care setting. Farmeconomia. Health economics and therapeutic pathways. 2013;14(4):133-9.

11. Jakovljevic MB. The key role of leading emerging BRIC markets for the future of global health care. Ser J Exp Clin Res. 2014;15(3):139-43. http://dx.doi.org/10.5937/ sjecr1403139J

12. Woodhead M, Blasi F, Ewig S, Garau J, Huchon G, leven $\mathrm{M}$, et al. Guidelines for the management of adult lower respiratory tract infections--full version. Eur Respir J. 2011;17 Suppl 6:E1-59.

13. Valencia M, Badia JR, Cavalcanti M, Ferrer M, Agustí C, Angrill J, et al. Pneumonia severity index class $\mathrm{V}$ patients with community-acquired pneumonia: characteristics, outcomes, and value of severity scores. Chest. 2007;132(2):515-22. http://dx.doi.org/10.1378/ chest.07-0306

14. Richards G, Levy H, Laterre PF, Feldman C, Woodward B, Bates BM, et al. CURB-65, PSI, and APACHE 11 to assess mortality risk in patients with severe sepsis and community acquired pneumonia in PROWESS. J Intensive Care Med. 2011;26(1):34-40. http://dx.doi. org/10.1177/0885066610383949

15. National Health Insurance Fund [homepage on the Internet]. Belgrade: Republic of Serbia [cited 2014 Aug 1]. Available from: http://www.eng.rfzo.rs/index.php/ about-us/about-us

16. Zweifel P. The Grossman model after 40 years. Eur J Health Econ. 2012;13(6):677-82. http://dx.doi.org/10.1007/ s10198-012-0420-9

17. Trading Economics [homepage on the Internet]. New York/Lisbon: Trading Economics [cited 2014 Aug 1]. Serbia Wages 2000-2015. Available from: http://www. tradingeconomics.com/serbia/wages.

18. Keitel K, Alcoba G, Lacroix L, Manzano S, Galetto-Lacour A, Gervaix A. Observed costs and health care use of children in a prospective cohort study on communityacquired pneumonia in Geneva, Switzerland. Swiss Med Wkly. 2014;144:w13925.
19. Jahnz-Rózyk K. Health economic impact of viral respiratory infections and pneumonia diseases on the elderly population in Poland. Pol Merkur Lekarski. 2010;29(169):37-40.

20. Lazic Z, Gajovic O, Tanaskovic l, Milovanovic D, Atanasijevic D, Jakovljevic M. GOLD Stage Impact on COPD Direct Medical Costs in Elderly. J Health Behav \& Pub Health. 2012;2(3):1-7.

21. Jakovljevic M, Lazic Z, Verhaeghe N, Jankovic S, Gajovic 0, Annemans L. Direct medical costs of COPD diagnosis and treatment, Eastern vs. Western European country-examples of Serbia and Belgium. Farmeconomia. Health economics and therapeutic pathways 2013;14(4):161-8.

22. Fine MJ, Pratt HM, Obrosky DS, Lave JR, Mclntosh LJ, Singer DE, et al. Relation between length of hospital stay and costs of care for patients with communityacquired pneumonia. Am J Med. 2000;109(5):378-85. http://dx.doi.org/10.1016/S0002-9343(00)00500-3

23. Biorac N, Jakovljevic MB, Stefanovic D, Perovic S, Jankovic S. Assessment of diabetes mellitus type 2 treatment costs in the Republic of Serbia. [Article in Serbian]. Vojnosanit Pregl. 2009;66(4):271-6. http://dx.doi.org/10.2298/ VSP0904271B

24. Jovanovic M, Jakovljevic M. Inpatient detoxification procedure and facilities: financing considerations from an Eastern European perspective. Alcohol Alcohol. 2011;46(3):364-5. http://dx.doi.org/10.1093/alcalc/agr010

25. Jakovljevic M, Varjacic M, Jankovic SM. Cost-effectiveness of ritodrine and fenoterol for treatment of preterm labor in a low-middle-income country: a case study. Value Health. 2008;11(2):149-53. http://dx.doi. org/10.1111/j.1524-4733.2007.00222.x

26. Jakovljevic M, Mijailovic Z, Jovicic BP, Canovic P, Gajovic O, Jovanovic M, et al. Assessment of viral genotype impact to the cost-effectiveness and overall costs of care for PEG-interferon-2 $\alpha+$ ribavirine treated chronic hepatitis C patients. Hepat Mon. 2013;13(6):e6750.

27. Jakovljevic MB. Oncology monoclonal antibodies expenditure trends and reimbursement projections in the emerging Balkan market. Farmeconomia. Health economics and therapeutic pathways. 2014;15(1):27-32.

28. Conterno LO, Moraes FY, Silva Filho CR. Implementation of community-acquired pneumonia guidelines at a public hospital in Brazil. J Bras Pneumol. 2011;37(2):152-9. http://dx.doi.org/10.1590/S1806-37132011000200004

29. Jakovljevic M, Jovanovic M, Rancic N, Vyssoki B, Djordjevic N. LAT Software Induced Savings on Medical Costs of Alcohol Addicts' Care--Results from a Matched-Pairs Case-Control Study. PLoS One. 2014;9(11):e111931. http://dx.doi.org/10.1371/journal.pone.0111931

\section{About the authors}

\section{Vojislav Cupurdija}

Internist. Pulmonology Department, University of Kragujevac Center for Clinical Medicine, Kragujevac, Serbia.

\section{Zorica Lazic}

Full Professor. Faculty of Medical Sciences, University of Kragujevac, Kragujevac, Serbia; and Head. Pulmonology Department, University of Kragujevac Center for Clinical Medicine, Kragujevac, Serbia.

\section{Marina Petrovic}

Vice-Dean. Faculty of Medical Sciences, University of Kragujevac, Kragujevac, Serbia; and Internist. Pulmonology Department, University of Kragujevac Center for Clinical Medicine, Kragujevac, Serbia.

\section{Slavica Mojsilovic}

Internist. Pulmonology Department, University of Kragujevac Center for Clinical Medicine, Kragujevac, Serbia. 


\section{Ivan Cekerevac}

Head. Intensive Care Unit, University of Kragujevac Center for Clinical Medicine, Kragujevac, Serbia.

\section{Nemanja Rancic}

Assistant Professor. Centre for Clinical Pharmacology, Medical Faculty, Military Medical Academy, University of Defence, Belgrade, Serbia.

\section{Mihajlo Jakovljevic}

Head. Graduate Program in Health Economics and Pharmacoeconomics, Faculty of Medical Sciences, University of Kragujevac, Kragujevac, Serbia. 